\title{
EFFECTS OF SCHOOL TYPE (DAY SCHOOL AND BOARDING SCHOOL) ON SECONDARY SCHOOL STUDENTS’ ACADEMIC ACHIEVEMENT IN SOCIAL STUDIES
}

\author{
ODE, Dickson (Ph. D) \\ Wesley High School, Otukpo
}

\begin{abstract}
This study investigated the effect that day school in collaboration with boarding school would have on secondary school students' academic achievement in social studies. The post-test only experimental design was adopted. One null hypothesis was formulated and tested at 0.05 level of significance. The instrument for data collection was a-25 item teacher made Social Studies Achievement Test (SOSAT) which was validated and reliability index of 0.83 was established. Using the simple random sampling technique, one junior secondary II (JS II) class made up 45 students from each of a day school and a boarding school was selected and divided into two groups namely experimental group (day school students) and control group (boarding school students) and investigated. Each of the two groups was taught social studies for 9 weeks by only one social studies teacher. At the end of the $9^{\text {th }}$ week of the study, the post-test was administered on the students to determine difference in academic performance if any between the two groups. Using means and t-test in analyzing the data, the result showed that, boarding school students significantly performed better than day school students in social studies. The study recommended among others that, government and individual day secondary schools should periodically organize workshops and seminars on how day school students can improve their academic performance in social studies and other subjects.
\end{abstract}

\section{KEYWORDS}

School type, secondary school students, academic achievement, social studies

\section{INTRODUCTION}

There are various types of school in the world today. This is in consonance with the view of Ajayi (2002). According to Ajayi, there are different classifications of school each of which influences learning outcome in a particular way. As indicated by Ajayi, these classifications include public schools, private schools, day schools, boarding schools, faith schools, secular schools, grammar school, vocational school, urban schools, rural schools, community schools, special schools, specialist schools, etc. Although, there are various school types of school, this study is only concerned with day school and boarding school as they affect learning outcomes.

Boarding school, as highlighted above, dated back to ancient times. According to Ehigie (2000), the boarding school system could be traced to the Greek system of education in Athens, Greece, whereby young males were sent to institutions to be trained as soldiers. After the boarding school system in Ancient Athens, modern boarding school system began to emerge. In an effort to provide the meaning of boarding school and why it emerged, Taiwo (2001) stated that, it (boarding school) involves the provision of learning and teaching activities with meals and 
accommodation to learners outside their original homes. According to Taiwo, providing boarding facilities to learners offers them (learners) a better opportunity of been kept from distractions at home and paves way for more concentration on academic activities in school. In line with the above view of Taiwo on the significance of boarding school, David (2004) stated that, boarding school system offers better opportunity for academic performance.

In another attempt at providing the meaning of boarding school, British Council (2019) sees it (boarding school) as a residential school where pupils live and study during the school year. By the above view of British Council on the meaning of boarding school, British Council is in unison with taiwo (2001) that, boarding school has to do with the provision of learning and teaching activities to learners within a different accommodation away from their homes. In the same vein, Boarding School Tours (2019) sees boarding school as a college preparatory institution where students and teachers live and study together in a safe and secure campus environment. Going by the meaning of boarding school as provided by Boarding School Tours, it is apparent that, Boarding School Tours is in concurrence with Taiwo (2001) and British Council (2019) as to what boarding school implies as they all emphasize keeping learners away from their original homes.

Also in a bid to unveil the meaning of boarding school, Grandreams (1996) views it (boarding school) as a school equipped with rooms where its students live instead of living in their homes. The definition of boarding school as provided by the above organization (grandreams) shows that, it is in accord with Boarding School Tours (2019), Taiwo (2001) and British Council (2019) as regards what boarding school means. In addition to unraveling the meaning of boarding school, Webster (2018) sees boarding school as a school that provides meals and lodging. The meaning of boarding school provided by Webster also shows that, Webster is in agreement with Grandreams (1996), Boarding school Tours (2019), Taiwo (2001), British Council (2019) and Webster (2018). Furthermore, Hornby (2010) views boarding school as a school where children can live within the school year. The meaning of boarding school as revealed by Hornby indicates that Hornby is not different from what the preceding authorities have said as to what boarding school implies. Also, in contribution to the meaning of boarding school, Eagle (1979) reveals that, it (boarding school) is a school in which pupils live during the term. The meaning of boarding school as unmasked by Eagle indicates that, Eagle is not in discord with the preceding authorities as to what boarding school implies as all the preceding authorities including Eagle emphasize the fact that, learners live in a different accommodation away from their original homes. From the meaning of boarding school as provided by the above authorities, it is indisputable to say that, boarding school is an educational system whereby learners are provided with learning and teaching activities alongside meals and accommodation.

In view of day school as reflected in the early part of the introduction, Ajayi (2002) revealed that, it (day school), was predated by the boarding school system of education which originated in ancient Athens. According to Ajayi, after the boarding school system of education in Ancient Athens that was meant to train soldiers, modern boarding school system began to emerge and was later followed by the evolution of day school system due to obvious reasons. As to what day school system implies and the reasons behind its evolution, Ajayi (2002) stated that, it (day school) involves creating a teaching and learning environment which operates only within the day as opposed to a boarding school which apart from providing teaching and learning, include the provision of feeding and accommodation facilities to learners. According to Ajayi, day school principally emerged due to low financial status of many parents who found it difficult to send their children to boarding schools as well as the huge financial implication of funding or establishing and maintaining boarding schools. Ajayi continued that, the emergence of day school gained momentum as it afforded parents the opportunity of providing the required academic education to their children and at the same time, obtaining domestic assistance from children and imparting social values in them (children) on regular basis. Ajayi also stated that, the day school 
system was embraced as it enabled parents the opportunity of assisting children in their school routine homework and thus enhance their academic performance. Ajayi's viewpoints are in line with the views of Keystone Tutors (2018). Keystone Tutors stated that, boarding school was highly expensive when compared to day school. It (Keystone Tutors) went further to buttress its stance by citing an instance where it stated that, annual average cost of sponsoring a child in a boarding school was $£ 27,600$ while the annual cost of sponsoring a child in a day school was $£ 1,700$ in United Kingdom. Keystone Tutors is also in unison with Ajayi (2002) as it is of the view that, a parent stands the chance of providing the child other out-of-school education to complement what the school provides.

In another effort to provide the meaning of day school, Webster (2016) viewed day school as a private elementary or secondary school held on weekdays without boarding facilities. The meaning of day school as provided by Webster appears cloudy as a day school may not necessarily be owned by private individuals or group but could also be owned by government.

Also, in a bid to provide the meaning of day school, Collins (1979) sees it (day school) as a school where students go home every evening and do not leave at school. The meaning of day school as provided by Collins appears to be in line with the view of Ajayi (2002) who indicated that, day school does not include the provision of feeding and accommodation facilities to learners but only involves the creating of teaching and learning environment to learners within the day.

In addition to providing the meaning of day school, Bullons (1978) viewed it as a school where students go home in the evening than one where students live in the school. The meaning of day school as revealed by Bullons shows that, Bullons is in agreement with the meanings of day school as provided by Ajayi (2002) and Collins (1978).

Furthermore, in a bid to unveil the meaning of day school, InterActiveCorp (1995) sees it as a school condition in a day time. A close look at the meaning of day school as provided by InterActiveCorp indicates that, InterActiveCorp shares similar view with Ajayi (2002), Collins (1979) and Bullons (1978) as to what day school implies. In the same vein, BBC English (1992) sees day school as a school where the pupils go home in the evening and do not live at the school. From the definition provided by BBC English, it is apparent that, BBC English in unison with Ajayi (2002), InterActiveCorp (1995), Collins (1979) and Bullons (1978) as to what day school means. In addition, Eagle (1979) views day school as school carried out in day time. By this definition (definition of day school), Eagle is not different from the views of Ajayi (2002), InterActiveCorp (1985), Collins (1979), Bullons (1978) and BBC Englih (1992) as regards the meaning of day school. From the meanings of day school provided by the above authorities, it suffices to say that, day school is a school system whereby pupils or students are exposed to teaching and learning during day time without provision of accommodation facilities. However, given the divided opinions on day school and boarding school in the foregoing passages as to which of the two is more significant than the other coupled with outcry on the falling standard of education today and the need to do everything possible to revive it as pointed out by Olugbenga (2016) and Duze (2011), it becomes pertinent to investigate the significance of school type with reference to day school and boarding school as they relate to academic output of learners. In a bid to determine the effects school of type on academic performance of learners, various related studies carried out in the past had focused more on the science subjects with nothing on social studies. It is against this backdrop that, the researcher sought to investigate the effects of school type on secondary school students' academic achievement in social studies. Specifically, the study sought to investigate the effect that day school used in collaboration with boarding school would have on secondary school students' academic achievement in social studies. 


\section{HYPOTHESIS}

The following hypothesis was tested at 0.05 level of significance in respect of the study. There is no significant difference between the mean achievement scores of students taught social studies in day school and the students taught social studies in boarding school

\section{MeTHOD}

In the study, post-test only experimental design was employed with one experimental group (day school students) and one control group (boarding school students). 90 junior secondary II students (JS II students) from two private co-educational secondary schools in one of the local government headquarters of the North Central geo-political zone of Nigeria were used as subjects for the study. Using the purposive sampling technique, two co-educational secondary schools (a day school and a boarding school) within the same locality (a local government headquarters in the North Central geo-political zone of Nigeria) were selected to ensure that both male and female students were represented. In each of the two schools where the subjects were drawn from, there were more than four classes of JS II (junior secondary II). Using the simple random sampling technique, one JS II class made up of 45 students from each of the two secondary schools (a day school and a boarding school) was selected. The teacher-constructed instrument used in the study is called Social Studies Achievement Test (SOSAT). The test (SOSAT) consisted of 25 items drawn from JS II social studies syllabus. The 25 items in SOSAT consisted of 20 multiple-choice and 5 essay type items based on the topics treated. The SOSAT was validated by one expert in social studies and one expert in measurement and evaluation to ensure both face and content validity using table of specifications. Using the Pearson Product Moment Correlation Coefficient, the reliability coefficient of SOSAT was 0.83 which indicated that, the instrument was reliable and appropriate for the study.

In line with the focus of the study, only one teacher was involved in teaching social studies in each of the two selected classes (one JS II class from day school and one JS II class from boarding school within the same locality). In the study, both the day school students and boarding school students were exposed to teaching and learning of social studies by the same teacher in accordance with the prescribed topics in social studies syllabus for nine weeks. At the end of the $9^{\text {th }}$ week of the study, the SOSAT was administered by the same teacher (the teacher who taught both the day school students and boarding school students) on both the day school students and boarding school students. In analyzing the data, the t-test statistics was applied

\section{RESULTS}

Ho: There is no significant difference between the mean achievement scores of students taught social studies in day school and the students taught social studies in boarding school.

Table 1: t-test analysis of the effect of school type on achievement scores of students in social studies

\begin{tabular}{lcccccc}
\hline Treatment & N & Mean & $\begin{array}{c}\text { Std. } \\
\text { Deviation }\end{array}$ & Df & T & Sig \\
\hline Day School & 45 & 45.02 & 13.21 & 88 & -10.408 & .000 \\
Boarding School & 45 & 75.86 & 14.76 & & & \\
\hline
\end{tabular}

Table 1 shows that, the students who attend day schools had mean achievement score of 45.02 with a standard deviation of 13.21 while those who attend boarding schools had mean 
achievement score of 75.86 with a standard deviation of 14.76. This shows that students who attend boarding schools had higher mean achievement score than those who attend day schools. Besides, the result shows that the calculated t (-10.408) for the effect of school type on achievement scores of students in social studies had an associated probability value of 0.000 . Since the probability value of 0.000 is less than the 0.05 level of significance, the null hypothesis was rejected, implying that there is a significant difference in the mean achievement scores of students taught social studies in day school and the students taught social studies in boarding school.

\section{DiscuSSION}

The findings of the study revealed that, there was significant difference in the mean achievement scores of students taught social studies in day school and students taught social studies in boarding school. This implies that, students who were taught social studies in boarding school significantly performed better than students taught social studies in day school. The above inferior performance of students in day school discovered in the study could be attributed to the fact that, students in day school are exposed to a lot of distractions at home after school hours as opposed to what obtains in boarding school where such distractions are highly minimized. Such distractions which in the long run adversely affect day school students' concentration on study or academic work include attending party, night club and film houses, engagement in unnecessary boy/girl relationships, uncontrolled watching of foreign football matches on air (satellite television viewing centres), engagement in domestic work, running errands for parents, indulgence in social media activities, improper feeding at home (lack of regular and balanced diet), etc. This inferior performance of day school students is in consonance with the findings of Misoy (2011) who found that, majority of day school students scored an average grade of ' $\mathrm{C}$ ' compared to majority of boarding school students who scored an average grade of ' $\mathrm{B}$ ' in controlled test.

\section{Conclusion}

Based on the findings of the study, it was concluded that, boarding school environment enhances higher academic achievement in social studies among secondary school students than day school environment. The study further revealed that, there was significant difference in the mean achievement scores of students taught social studies in day school and students taught social studies in boarding school.

\section{RECOMMENDATIONS}

The study made the following recommendations

- Government and individual day schools should periodically organize workshops and seminars on how day school students can improve their academic performance in social studies and other subjects.

- Parents should strive hard to ensure that, they significantly reduce the extent to which they engage day school students in domestic work.

- School guidance counsellors should redouble their efforts in sensitizing day school students on the adverse effects of unnecessary boy/girl relationships, uncontrolled watching of foreign football matches on air (satellite television viewing centres), uncontrolled partying and night clubbing on their studies. 
- School guidance counsellors should also seriously sensitize parents of day school students on the need for them (parents) to significantly reduce the burden of domestic work placed on day school students so as to enable them (day school students) have enough time for their studies after school hours.

- Parents should ensure that, their children who are day school students avoid peers that are mischievous and have no regard for academic work..

- Government should as a matter of policy, ensure that, day secondary school students remain in the school premises till evening before they go home. This is to enable them (day school students) more time to read or study and thus reduce the extent to which they waste precious time at home doing unnecessary things.

- Parents should always ensure that, their children who are day school students are properly fed to enable them (day school students) concentrate on their studies.

- Parents should also strive hard to check indulgence in social media activities by children who are day school students.

\section{REFERENCES}

1. Ajayi, F.A.O. (2002). School environment and learning. Lagos. Genuine Printers.

2. BBC English (1992). BBC English dictionary. London. Herpers Collins Publishers.

3. Boarding School Tours (2019). Boarding school. Retrieved $12^{\text {th }}$ January, 2019 from https://www.boarding schooltours..c..

5. British Council (2019). Boarding school. Retrieved $4^{\text {th }}$ January, 2019 from https://study.uk. Britishcoun...

6. Bullons, S. (1979).Day school. Retrieved $6^{\text {th }}$ September, 2018 from http://www.idoceonline.com> dictionary

7. Collins, S. (1979). Collins English dictionary. Retrieved $16^{\text {th }}$ September, 2018 from https://www.collins.dictionary.com >day

8. David, A. A. (2001). School type and learning outcome. Lagos. Bill \& Fab.

9. Duze, C. O. (2011). Falling standard of education in Nigeria: an empirical evidence in Niger Delta. Journal of Contemporary Research, Vol. 8 (3).

10. Eagle, D. (1979). The oxford illustrated English dictionary. Oxford. Oxford University Press.

12. Ehigie, B.O. (2000). A comparative study of academic performance of boarding and day school students. Retrieved $2^{\text {nd }}$ September, 2018 from https://project.com

13. Grandreams (1996), Cambridge English dictionary. Retrieved $3^{\text {rd }}$ September, 2018 from https://dictionary.cambridge

14, Hornby A. S.(2010). Oxford advanced learners dictionary of current English. Oxford. Oxford University Press. 
International Journal of Education (IJE) Vol.7, No.1, March 2019

15. InterActiveCorp (1995). Day school. Retrieved $2^{\text {nd }} \quad$ Serptember,2018 from https://www.dictionary.com>browse

16. Keystone Tutors (2018). Top five reasons to choose day school over boarding school. Retrieved $5^{\text {th }}$ September, (2018) from https://keystonetutors.com

17. Misoy, E.C. (2011). Factors affecting academic performance of day secondary school in Nandi district, Kenya. Retrieved $2^{\text {nd }}$ September, 2018 from https://www.curren.irrlibrary.ku.ac/kehandle/123456789/756

18. Olugbenga, O. (2016). Falling standard of education in Nigeria: the causes and permanent solutions Retrieved $4^{\text {th }}$ August, 2018 from https//www.google.com/amps/gbengaogun om/2016/06/27/fallingstandard-ofeducation-in-nigeria-the-causes-and-permanent- solu tions/amps/

19. Taiwo, E. A. (2001). School environment and learners' development. Lagos. Pat and Fab Press

20, Webster, N. (2018). Day school. Retrieved $7^{\text {th }} \quad$ September, 2018 from https://www.meriam.webster_we... 